\title{
Hypertrophic Pachymeningitis as an Early Manifestation of Relapsing Polychondritis: Case Report and Review of the Literature
}

\author{
Satoru Ushiyama Tomomi Kinoshita Yasuhiro Shimojima \\ Nobuhiko Ohashi Dai Kishida Daigo Miyazaki Katsuya Nakamura \\ Yoshiki Sekijima Shu-ichi Ikeda \\ Department of Medicine (Neurology \& Rheumatology), Shinshu University School of \\ Medicine, Matsumoto, Japan
}

\section{Keywords}

Relapsing polychondritis · Hypertrophic pachymeningitis · Auricular chondritis · Neurological involvement

\begin{abstract}
Neurological involvement in relapsing polychondritis (RP) is relatively rare. We describe the case of an 80-year-old man who presented with hypertrophic pachymeningitis (HP) together with arthritis as the first manifestation of RP. Auricular chondritis, which subsequently determined the diagnosis of RP, occurred a few weeks after the detection of HP. The neurological symptoms, as well as arthritis, were promptly improved by treatment with corticosteroids. It is generally difficult to diagnose RP in the absence of typical cartilaginous involvement; however, the present case suggests that HP may occur as an early clinical manifestation of RP.
\end{abstract}




\section{Case Reports in Neurology}

\section{Introduction}

Relapsing polychondritis (RP) is an autoimmune disease that affects cartilaginous tissue and proteoglycan-rich structures causing chronic inflammation [1, 2]. Symptoms generally involve the eyes, elastic cartilaginous structures of the nose and ears, respiratory tract including the laryngeal and tracheal cartilage, or hyaline cartilage of joints $[3,4]$. The central nervous system is also recognized as an episodic target of RP, resulting in cranial neuropathies, encephalitis, meningitis, and ischemic stroke [5]. However, hypertrophic pachymeningitis (HP), which is an inflammatory disorder that causes focal and diffuse thickening of the dura mater, is uncommon in RP patients. Herein, we describe the case of a patient with RP who presented with HP as an early clinical manifestation of RP. To our knowledge, this is the first case where HP occurred prior to the diagnosis of RP.

\section{Case Report}

An 80-year-old man presenting with headache, deafness on the right side, sensory disturbance on the left side of the face, and gait disturbance ascribable to remarkable dizziness, as well as bilateral arthralgia of the wrists, was admitted to our hospital. Magnetic resonance imaging (MRI) of the brain revealed diffuse thickening of the dura mater with gadolinium enhancement on T1-weighted images, in the falx cerebri, convexity, and tentorium cerebelli, which was compatible with HP (fig. 1a, b). In the systemic assessment at admission, no inflammatory findings were demonstrated in the oral cavity, eyes, inner or external ears, skin, upper or lower respiratory tracts, cardiovascular system, digestive system, kidney, or urinary tract, despite bilateral tenderness with mild swelling in the wrist joints and neurosensory deafness. There were no abnormal findings suggestive of malignancy. Blood and biochemical examinations at admission revealed mild increases of white blood cell count $(9,200 / \mu \mathrm{l})$ and C-reactive protein (CRP) level $(0.85 \mathrm{mg} / \mathrm{dl})$, while results of all serum examinations, including those for rheumatoid factor, anti-nuclear antibodies, anti-dsDNA antibody, anti-SS-A antibody, anti-SS-B antibody, proteinase 3 anti-neutrophil cytoplasmic antibody (ANCA), myeloperoxidase ANCA, and angiotensin-converting enzyme were negative. The IgG4 titer was within the normal range $(77 \mathrm{mg} / \mathrm{dl})$. A cerebrospinal fluid (CSF) examination revealed elevation of protein levels $(78 \mathrm{mg} / \mathrm{dl})$, pleocytosis (57 cells $/ \mu \mathrm{l}, 100 \%$ monocytes), and a high IgG index (1.9) with normal intracranial pressure. No atypical cells were found in cytological examination of the CSF. Tests of infection in the CSF, including cultures for bacterial or fungal infections, and the polymerase chain reaction test for tuberculosis were all negative. Three weeks after the demonstration of HP on MRI, right ear swelling appeared with CRP levels rising to $5.8 \mathrm{mg} / \mathrm{dl}$, and abnormal uptake was observed in the right ear in gallium-67 scintigraphy (fig. $2 \mathrm{a}, \mathrm{b}$ ), resulting in the diagnosis of RP according to the criteria described by Michet et al. [4]. Following the administration of $100 \mathrm{mg}$ intravenous hydrocortisone for 3 days, oral prednisolone was administered at a dose of $20 \mathrm{mg}$ daily, resulting in normalization of the CRP level and an immediate improvement of all symptoms, except for the right-sided deafness, which partially remained. The MRI finding of the gadoliniumenhanced dura mater was also improved (fig. 1c, d). Oral prednisolone was successfully reduced without relapse. 


\section{Discussion}

Neurological symptoms are recognized as relatively rare complications in RP, especially at the onset of disease [1], when compared with the involvement of auricular, ocular, nasal, respiratory, or cardiovascular systems. Nevertheless, it has been reported that $9.7 \%$ of patients with RP developed central nervous system involvement [6]. HP is an inflammatory disorder that occurs secondary to intracranial infections, neoplastic diseases, and some autoimmune disorders such as ANCA-associated vasculitis (AAV), sarcoidosis, and IgG4-related disease [7]. To our knowledge, only four cases of HP related to RP have been reported in two original articles [8, 9] (table 1). However, AAV was also demonstrated in three of those cases, suggesting that AAV might affect the occurrence of HP; incidentally, AAV is the most common cause of HP [7]. Considering the pathogenesis of RP, underlying vasculitis is frequently observed, especially in patients with neurological manifestations [2]. Furthermore, the possible overlap between RP and AAV has been previously indicated [1, 2]. However, our case did not have any other apparent secondary causes of HP during systemic assessment. According to the epidemiological descriptions of RP, concurrent autoimmune diseases, including not only systemic vasculitis but also several connective tissue diseases, are complicated and occur in more than $30 \%$ of RP patients [3]. Therefore, the present case may be valuable in order to describe HP related to RP without the interactions of other pathologies.

In another case of HP related to RP, HP occurred more than 1 year after the onset of RP (table 1). Meanwhile, the present case presented with auricular chondritis, which is the representative and most common characteristic of RP [1-4], a few weeks after the appearance of neurological symptoms associated with HP. Ultimately, auricular chondritis together with the persistence of seronegative polyarthritis and neurosensory hearing loss led us to make the definitive diagnosis of RP according to the prevalent criteria [4], although these manifestations were insufficient to fulfill other diagnostic criteria $[3,10]$. We recognize that this is the first report of HP related to RP prior to the typical cartilaginous involvement. In the cohort of patients with HP, 44\% were classified as idiopathic HP [7], whereas histopathological findings in the dura mater from idiopathic HP patients demonstrated inflammatory cell infiltration, fibrosis, and/or vasculitis, suggesting that the pathogenesis of idiopathic HP might be associated with connective tissue and collagen vascular diseases [11]. Considering these issues, some aspects of idiopathic HP may be the preceding state before the diagnosis of autoimmune diseases. Accordingly, it is suggested that HP may occur as the initial clinical manifestation of RP before the appearance of visible cartilaginous involvement. Although the pathogenesis of RP is still uncertain, T-cell-mediated immunity and inflammatory cytokines, including interleukin-1 $\beta,-6$, and -8 , are suggested as indicators of RP $[12,13]$. In addition, antibodies against the cartilage matrix protein known as matrilin- 1 and several types of collagen, such as type II, IX, and XI, have been described as causative agents of RP [14]. Overall, the mechanism of RP could be explained by these candidate immune mediators attacking proteoglycan-rich structure and cartilaginous tissue. Furthermore, the susceptibility of the dura mater tissue may be considered in the pathogenesis of RP. With regards to the anatomical background, the inner surface of the dura mater includes fibroblasts and fine collagen fibers which may consist of proteoglycans [15]. Accordingly, the dura mater also has an affinitive component to the pathogenesis of RP. However, a definitive relationship between these causative agents and the histological background of the dura mater has yet to be demonstrated.

It is usually difficult to make a definitive diagnosis of RP before the appearance of the typical cartilaginous involvement. Moreover, the specific symptoms for determining the 
Ushiyama et al:: Hypertrophic Pachymeningitis as an Early Manifestation of Relapsing Polychondritis: Case Report and Review of the Literature

diagnosis of RP are not entirely seen during the early phase of disease [2]. The present case suggests that HP may occur as the initial manifestation of RP. However, it is necessary to accumulate additional clinical experience and explore the immunopathological mechanisms in order to clarify the details of this disease.

\section{Statement of Ethics}

Informed consent was obtained from the patient.

\section{Disclosure Statement}

The authors declare that they have no financial or personal conflicts of interest.

\section{References}

1 Vitale A, Sota J, Rigante D, Lopalco G, Molinaro F, Messina M, et al: Relapsing polychondritis: an update on pathogenesis, clinical features, diagnostic tools, and therapeutic perspectives. Curr Rheumatol Rep 2016;18:3.

2 Sharma A, Gnanapandithan K, Sharma K, Sharma S: Relapsing polychondritis: a review. Clin Rheumatol 2013;32:1575-1583.

-3 McAdam LP, O’Hanlan MA, Bluestone R, Pearson CM: Relapsing polychondritis: prospective study of 23 patients and a review of the literature. Medicine (Baltimore) 1976;55:193-215.

4 Michet CJ Jr, McKenna CH, Luthra HS, O’Fallon WM: Relapsing polychondritis. survival and predictive role of early disease manifestations. Ann Intern Med 1986;104:74-78.

-5 Stewart SS, Ashizawa T, Dudley AW Jr, Goldberg JW, Lidsky MD: Cerebral vasculitis in relapsing polychondritis. Neurology 1988;38:150-152.

6 Zeuner M, Straub RH, Rauh G, Albert ED, Scholmerich J, Lang B: Relapsing polychondritis: clinical and immunogenetic analysis of 62 patients. J Rheumatol 1997;24:96-101.

7 Yonekawa T, Murai H, Utsuki S, Matsushita T, Masaki K, Isobe N, et al: A nationwide survey of hypertrophic pachymeningitis in Japan. J Neurol Neurosurg Psychiatry 2014;85:732-739.

8 Canas CA, Diaz-Martinez JC, Tobon GJ: Combination of hypertrophic pachymeningitis, PR3-ANCApositive vasculitis, and relapsing polychondritis. J Rheumatol 2011;38:966-967.

>9 Nakamura K, Sugaya K, Nakata Y, Shima S, Moutoh T, Nakano I: Hypertrophic pachymeningitis and encephalitis in a patient with relapsing polychondritis. Neurol Clin Neurosci 2015;3:42-43.

10 Damiani JM, Levine HL: Relapsing polychondritis - report of ten cases. Laryngoscope 1979;89:929-946.

11 Riku S, Kato S: Idiopathic hypertrophic pachymeningitis. Neuropathology 2003;23:335-344.

12 Buckner JH, Van Landeghen M, Kwok WW, Tsarknaridis L: Identification of type II collagen peptide 261-273-specific T cell clones in a patient with relapsing polychondritis. Arthritis Rheum 2002;46:238-244.

13 Stabler T, Piette JC, Chevalier X, Marini-Portugal A, Kraus VB: Serum cytokine profiles in relapsing polychondritis suggest monocyte/macrophage activation. Arthritis Rheum 2004;50:3663-3667.

$\$ 14$ Buckner JH, Wu JJ, Reife RA, Terato K, Eyre DR: Autoreactivity against matrilin-1 in a patient with relapsing polychondritis. Arthritis Rheum 2000;43:939-943.

15 Gartner LP: Textbook of Histology, ed 4. Philaderphia, Elsevier Health Sciences, 2015, pp 240-241.

S.U. and T.K. contributed equally to this work 


\section{Case Reports in Neurology}

\begin{tabular}{l|l}
\hline Case Rep Neurol 2016:8:211-217 \\
\hline DOI: 10.1159/000450850 & $\begin{array}{l}\text { C 2016 The Author(s). Published by S. Karger AG, Basel } \\
\text { www.karger.com/crn }\end{array}$ \\
\hline
\end{tabular}

Ushiyama et al.: Hypertrophic Pachymeningitis as an Early Manifestation of Relapsing Polychondritis: Case Report and Review of the Literature
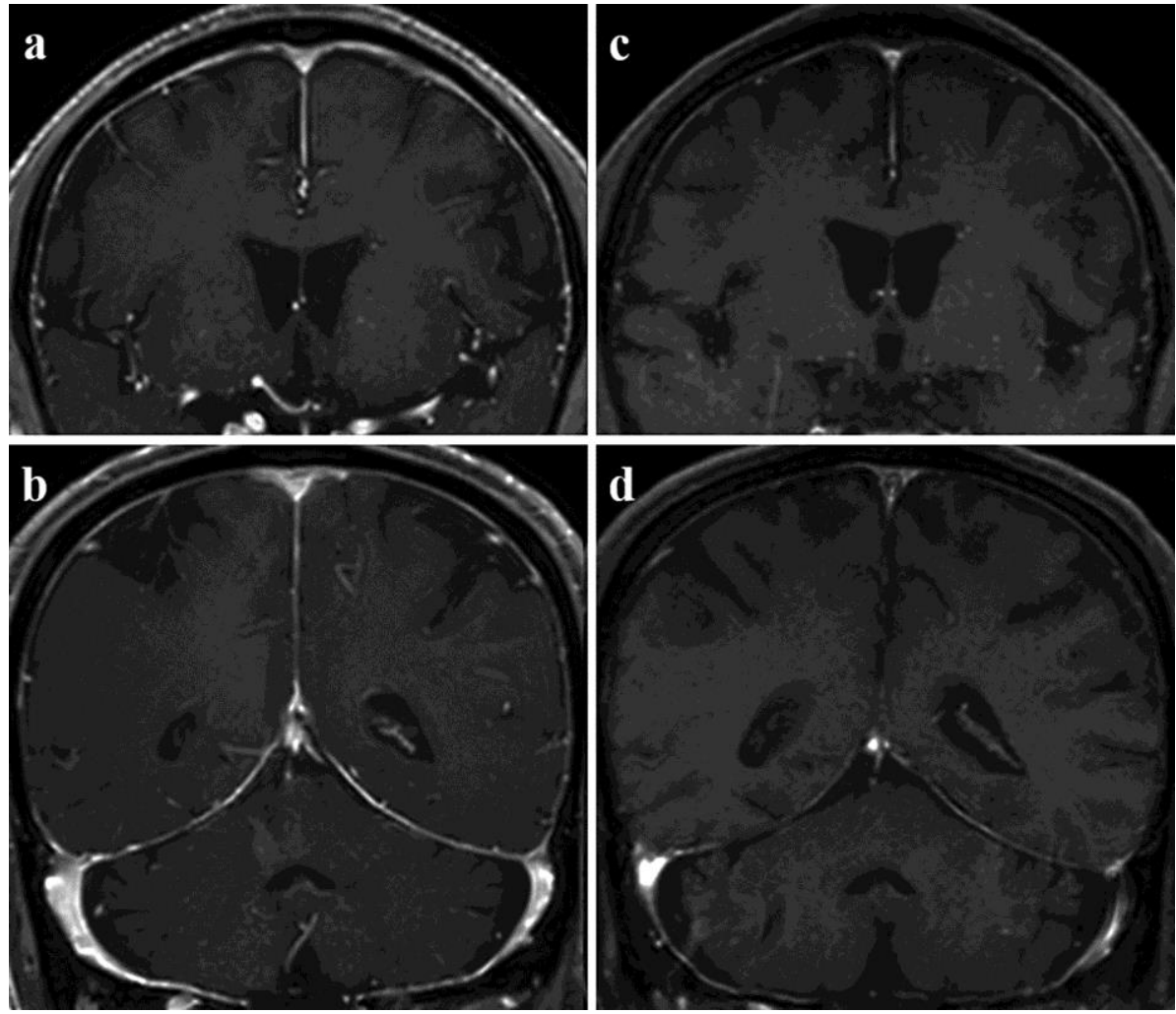

Fig. 1. Brain magnetic resonance imaging (MRI) with gadolinium-enhancement on T1-weighted image. Thickened dura mater was diffusely shown in the falx cerebri, convexity, and tentorium cerebelli $(\mathbf{a}, \mathbf{b})$. The MRI findings improved after treatment (c, d). 


\section{Case Reports in Neurology}

\begin{tabular}{l|l}
\hline Case Rep Neurol 2016;8:211-217 \\
\hline DOI: 10.1159/000450850 & $\begin{array}{l}\text { C 2016 The Author(s). Published by S. Karger AG, Basel } \\
\text { www.karger.com/crn }\end{array}$ \\
\hline
\end{tabular}

Ushiyama et al:: Hypertrophic Pachymeningitis as an Early Manifestation of Relapsing Polychondritis: Case Report and Review of the Literature
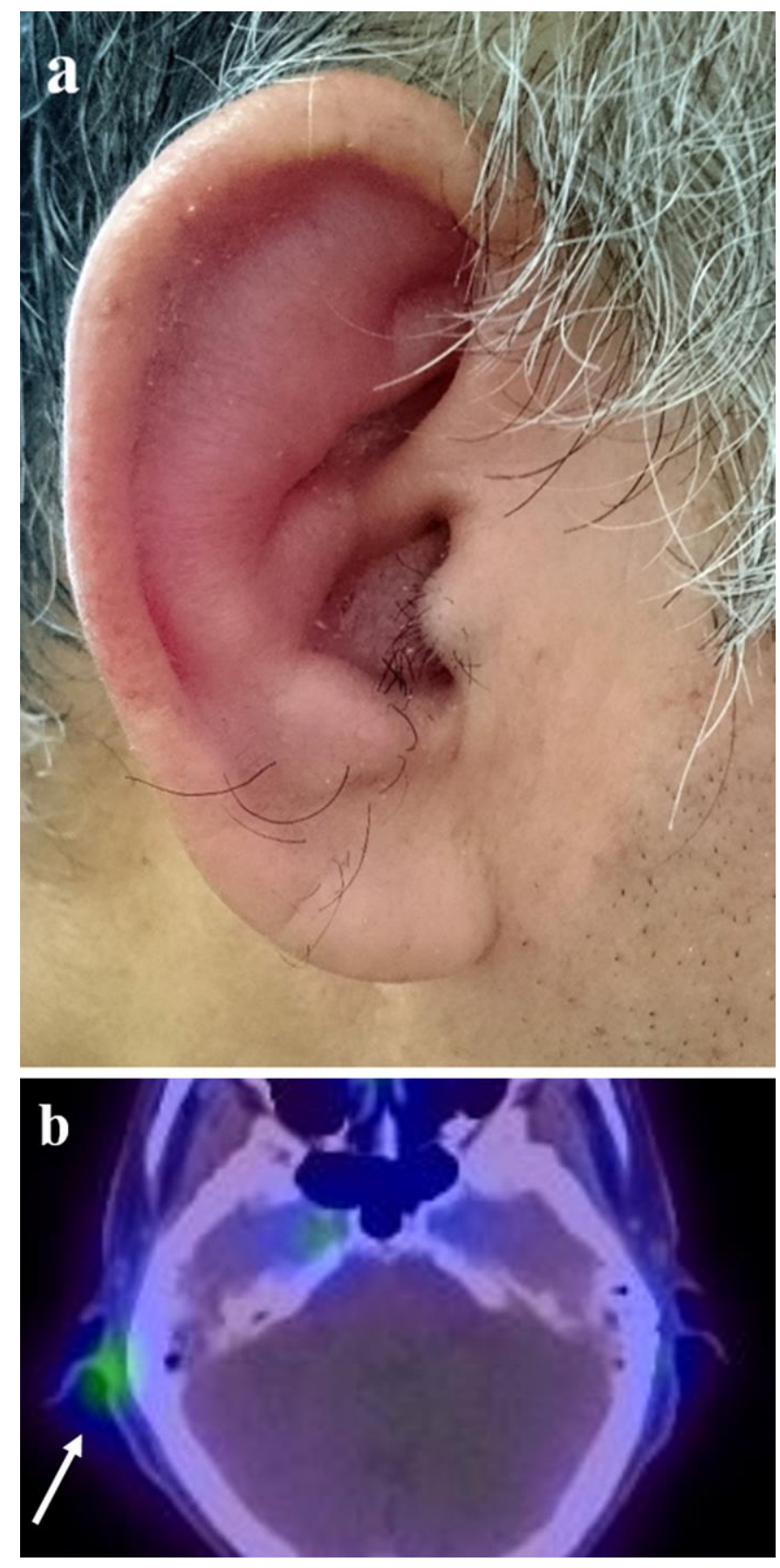

Fig. 2. Swelling of the ear on the right side (a) and abnormal uptake in the ipsilateral ear in gallium-67 scintigraphy (b). The swelling of ear was seen in the cartilaginous pinna without including the soft lobule. 


\section{Case Reports in Neurology}

Ushiyama et al.: Hypertrophic Pachymeningitis as an Early Manifestation of Relapsing Polychondritis: Case Report and Review of the Literature

Table 1. Review of reported cases of HP related to RP

\begin{tabular}{|c|c|c|c|c|c|c|c|c|}
\hline $\begin{array}{l}\text { Authors } \\
\text { [Ref.] }\end{array}$ & $\begin{array}{l}\text { Case } \\
\text { (age, years/ } \\
\text { sex) }\end{array}$ & $\begin{array}{l}\text { Site of } \\
\text { chon- } \\
\text { dritis }\end{array}$ & $\begin{array}{l}\text { Period } \\
\text { of HP } \\
\text { diagnosis }\end{array}$ & Symptoms & Site of HP & $\begin{array}{l}\text { Related } \\
\text { complications }\end{array}$ & $\begin{array}{l}\text { Treat- } \\
\text { ment }\end{array}$ & $\begin{array}{l}\text { Outcome of } \\
\text { HP }\end{array}$ \\
\hline \multirow[t]{3}{*}{$\begin{array}{l}\text { Canas } \\
\text { et al. [8] }\end{array}$} & $50 /$ female & $\begin{array}{l}\text { Ear, } \\
\text { trachea }\end{array}$ & ND & $\begin{array}{l}\text { Headache, facial sensory } \\
\text { impairment, episcleritis, } \\
\text { arthralgia, proteinuria, } \\
\text { hematuria }\end{array}$ & $\begin{array}{l}\text { Left cerebro- } \\
\text { pontine angle }\end{array}$ & $\begin{array}{l}\text { Renal vasculitis with PR3- } \\
\text { ANCA positivity }\end{array}$ & Cs & $\begin{array}{l}\text { Repeated } \\
\text { relapse }\end{array}$ \\
\hline & $\overline{48 / \text { female }}$ & $\begin{array}{l}\text { Ear, } \\
\text { nose }\end{array}$ & ND & $\begin{array}{l}\text { Headache, diplopia, deafness, } \\
\text { arthralgia, proteinuria, } \\
\text { hematuria }\end{array}$ & $\begin{array}{l}\text { Convexity } \\
\text { diffusely }\end{array}$ & $\begin{array}{l}\text { Renal vasculitis with PR3- } \\
\text { ANCA positivity }\end{array}$ & $\begin{array}{l}\mathrm{Cs}, \\
\mathrm{CPA}\end{array}$ & Improved \\
\hline & $\overline{50 / \text { female }}$ & $\begin{array}{l}\text { Ear, } \\
\text { nose, } \\
\text { trachea }\end{array}$ & ND & $\begin{array}{l}\text { Headache, multiple cranial } \\
\text { nerve palsy, weight loss, } \\
\text { arthralgia, episcleritis }\end{array}$ & Pontine zone & $\begin{array}{l}\text { Granulomatosis vasculitis } \\
\text { in the meningeal tissue } \\
\text { with PR3-ANCA positivity }\end{array}$ & $\begin{array}{l}\text { Cs, } \\
\text { CPA, } \\
\text { RTX }\end{array}$ & $\begin{array}{l}\text { Poor } \\
\text { response to } \\
\text { Cs }\end{array}$ \\
\hline $\begin{array}{l}\text { Nakamura } \\
\text { et al. [9] }\end{array}$ & $81 /$ female & $\begin{array}{l}\text { Ear, } \\
\text { trachea }\end{array}$ & $\begin{array}{l}1.5 \text { years } \\
\text { after RP } \\
\text { onset }\end{array}$ & $\begin{array}{l}\text { Conjunctivitis, scleritis, } \\
\text { progressive cognitive dys- } \\
\text { function, limb myoclonus, } \\
\text { bilateral cogwheel rigidity }\end{array}$ & $\begin{array}{l}\text { Bilateral } \\
\text { frontal, } \\
\text { falx cerebri }\end{array}$ & Encephalitis & $\begin{array}{l}\text { Cs, } \\
\text { AZA }\end{array}$ & Improved \\
\hline $\begin{array}{l}\text { Present } \\
\text { case }\end{array}$ & $80 /$ male & Ear & $\begin{array}{l}3 \text { weeks } \\
\text { before RP } \\
\text { diagnosis }\end{array}$ & $\begin{array}{l}\text { Headache, deafness, facial } \\
\text { sensory impairment, arthral- } \\
\text { gia }\end{array}$ & $\begin{array}{l}\text { Convexity diffuse- } \\
\text { ly, falx cerebri, tentori- } \\
\text { um cerebelli }\end{array}$ & None & Cs & Improved \\
\hline
\end{tabular}

$\mathrm{HP}=$ Hypertrophic pachymeningitis; RP = relapsing polychondritis; ND = not described; $\mathrm{Cs}=$ corticosteroid; $\mathrm{CPA}=$ cyclophosphamide; RTX = rituximab; $\mathrm{AZA}=$ azathioprine. 